\title{
SMS Based Exam Schedule Information Unit Link Using Data Protocol Method
}

\author{
Saeful Bahri1 ${ }^{1}$, Syarifah Fadillah Rezky², Junus Sinuraya ${ }^{3}$ \\ Budi Darma University ${ }^{1}$, Stmik Triguna Dharma ${ }^{2}$, Junus Sinuraya ${ }^{3}$ \\ Email : saeful.bahri@gmail.com¹, ikic5500@gmail.com², junussinuraya@polmed.ac.id ${ }^{3}$
}

Received : 14 Oktober 2019

Revised : 24 November 2019

Accepted : 26 November 2019

\section{(C) 2019 The Author: Published by. Cattleya Darmaya Fortuna}

\begin{abstract}
SMS from these various considerations is feasible to use. The level of ownership of cellular phones and affordable costs are considerations that support the adoption of this technology to be widely applied for the application of information system development in the present and in the future.Distance and long time are no longer a problem that can hinder obtaining information about the exam schedule, the SMS received does not come directly from the sender, but comes from the SMS Center. So, before the SMS reaches the recipient, the SMS actually enters the SMS Center first, The PDU contains not only the message, but also a lot of information about the sender. Starting from the sender's number, the sender's SMSC number, the validity time of the SMS, and so on. Everything is built in the form of hexadecimal numbers. SMS-based student exam scheduling using AT Command GSM which is used as a command in communication with the serial port. Scheduling with the AT command technique is very effective as information for students.
\end{abstract}

Keywords: Information, Exam Schedule, SMS Unit Link, Data Protocol Method.

\section{INTRODUCTION}

Along with increasing teCommunication technology is now very fast with the increasing demand for this technology [1]. These developments provide several facilities that can be used by users of communication services, such as Short Message Services [2]. PAt first this message was used between mobile phones, but with the development of technology, the message can be done via a computer or landline [3]. Short Message Service (SMS) is one of the features of GSM which was developed and standardized by the European Telecommunication Standards Institute (ETSI) [4]. SMS (Short Messaging Service) is one of the most widely used services by society today, in addition to being able to be used as a sender of SMS messages, SMS can also be used as a transfer of data or information in a small capacity [5]. This Short Message Service-based application provides facilities for users to carry out activities that are not limited by space and time, simply by using a cell phone [6]. SMS-based information system from these various considerations is feasible to use [7]. The level of ownership of cellular phones and affordable costs are considerations that support the adoption of this technology to be widely applied for the application of information system development in the present and in the future [8]. For example, a -based exam information system applicationShort Message Service on students. Information access services can be implemented using a gateway that connects information service providers with the Global System for Mobile Communications (GSM) network [9]. The gateway will automatically access the information service provider database and if the information is obtained it will be sent to the user who made the request.One of the technologies currently developing is the Global System for Mobile communication (GSM) 
or better known as digital cellular telephones [10]. GSM is used as a global standard for cellular communication as well as cellular technology that is most widely used by people around the world [11]. In general, it is difficult to get information on the exam schedule without having to be present at the study site in question, especially if the announcement of the exam schedule is late. Although it is difficult, it is possible to share exam schedule information for those who need it without having to be present at the place of study in question [12]. AdaThis application will make it easier for students to get information about the time of the exam and when it will be held. The exam schedule information service was created to assist students in getting information about the exam schedule on campus [13]. In this study the authors designed a system that utilizes Short Message Service as a medium to share exam schedule information for those in need. Thus the information service that will be designed can be enjoyed and immediately obtained the information needed by students, so that distance and long time are no longer a problem that can hinder obtaining information about the exam schedule. It is very important for students to get information about the exam schedule that will be carried out, therefore it is necessary to design an application that functions as an information system. This information application utilizes technology that has been tested for its existence and is often used by every student, which is based on Short Messaging Service.

\section{METHODS}

\section{SMS (Short Message Service) technology}

Short Message Service is one of the messaging features defined by the European Telecommunication Standard Institute (ETSI) standard, which is the specification-making body for GSM. Short Message Service is a mobile application that provides services for sending and receiving short messages in the form of letters and numbers from or to mobile devices [14]. Short Message Service as a document on GSM 03.40 and GSM 03.38 which can contain text up to 160 characters (standard character is generally 160) where each character is counted with a value of 7 bits. In addition to the 7-bit ones, there are also SMS messages with an 8-bit value but the characters are limited to 140 and are used for pictures and ringtones [15].

\section{MeHow SMS (Short Message Service) Works}

AWith the existence of a Short Message Service (SMSC) server, users can find out the status of the sent Short Message Service, whether it has arrived or failed to be received by the destination cellphone [16]. If the destination cellphone is active and receives the Short Message Service sent, the Short Message Service will send a confirmation message back to the Short Message Service center stating that the Short Message Service has been received, then the Short Message Service center will send the status back to the sender. However, if the destination phone is inactive or out of range, the Short Message Service sent will be stored in the Short Message Service center until the validity period is met.

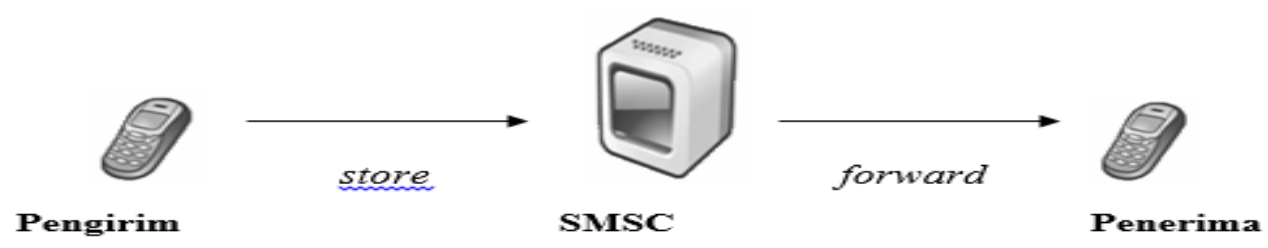

Figure 1: How the Short Message Service Works

Source: SaInfotech Institute, 2005 


\section{Protocol Data Unit}

There are 2 ways to send and receive SMS, namely by text and PDU. The text method is only used on some cell phone models. This text way is just a way of encoding the bitstream the PDU represents. If this method is implemented, the application must limit it by specifying the encoding options. If the PDU method is used, any encoding can be applied. The PDU contains not only the message, but also a lot of information about the sender. Starting from the sender's number, the sender's SMSC number, the validity time of the SMS, and so on. Everything is built in the form of hexadecimal numbers. Every SMS sent will go through a conversion process to PDU format, as well as when receiving SMS. The PDU for sending SMS and the PDU for receiving SMS are different.

\section{Protocol Data Unit Sending SMS}

Before reaching the recipient, the short message to be sent will be via SMSC (not in its original form, but first converted into PDU format, which consists of a combination of hexadecimal numbers). In general, the PDU for sending SMS consists of 8 parts[17].

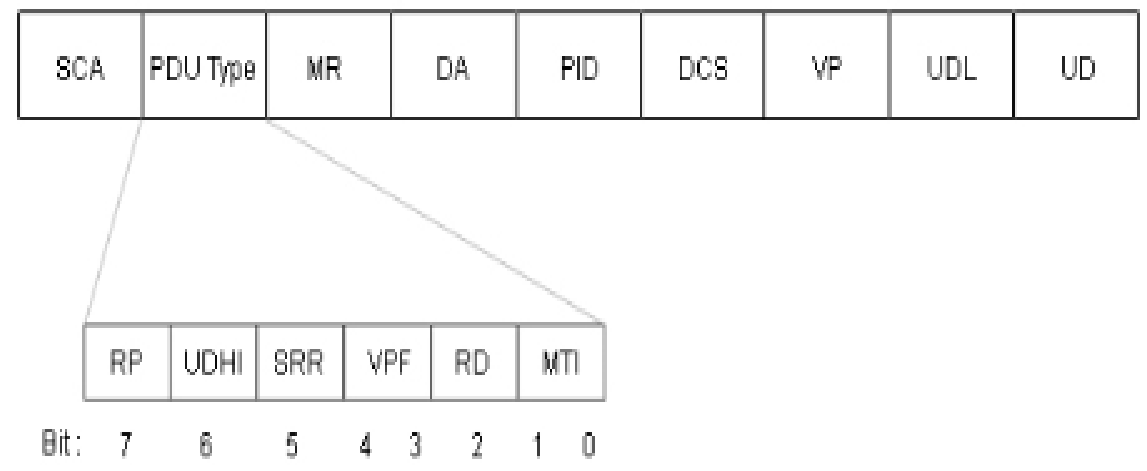

Figure 2: Submit SMS

\section{Protocol Data Unit For Receiving SMS}

SMS received does not come directly from the sender, but comes from the SMS Center. So, before the SMS reaches the recipient, the SMS actually enters the SMS Center first, then the SMS Center forwards it to the recipient. In Figure 4 below, you can see the arrangement of the SMS Deliver data section. It can be seen in Figure 4 that the data section is a parameter.

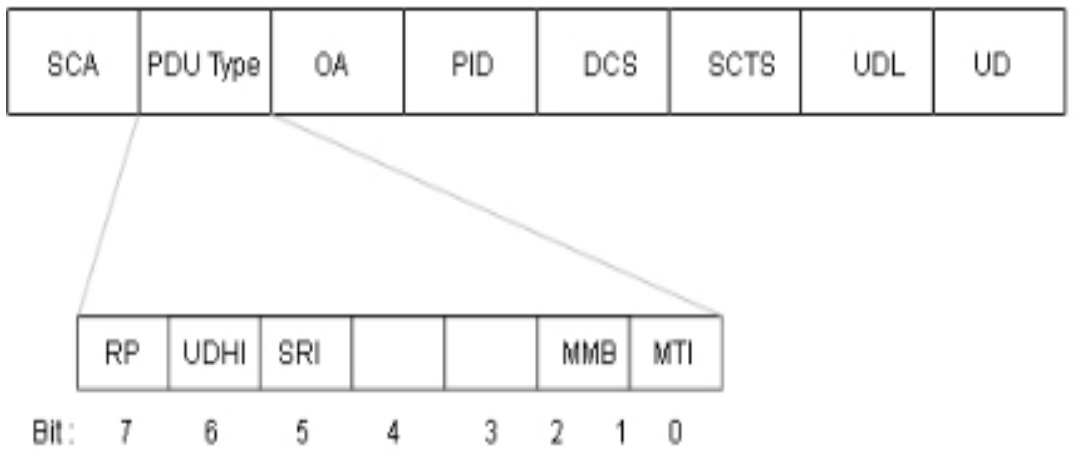

Figure 3: Data Structure Submit SMS 


\section{RESULTS \& DISCUSSION}

\section{Device Implementation}

The hardware in question is all the equipment needed to operate a computer system. Software specification aims to specify the software used in the manufacture of a system. Without software, the computerized process is impossible.

The hardware that the author uses in making this SMS system, among others:

1. Compaq 14 inch monitor with $1366 \times 768$. resolution

2. Processor Intel Pentium

3. Hard disk 500GB

4. Memory with a capacity of $1 \mathrm{~GB}$

5. Mouse and Keyboard as a data input tool

6. Nexian G522 . data cable

7. WL Nexian G522 as a medium for sending SMS in the system.

8. Nokia Mobile which is used as a Mobile Client to receive SMS from the server.

Mobile data cable is plugged into the serial port of the computer, the MT6225 USB Modem Driver port (COM 3) will appear as the modem from the cellphone that will be used for the SMS system. Henceforth COM 3 can be used in Visual Basic 6.0 applications in the Port Settings of the SMS system. For more details, see the following image:

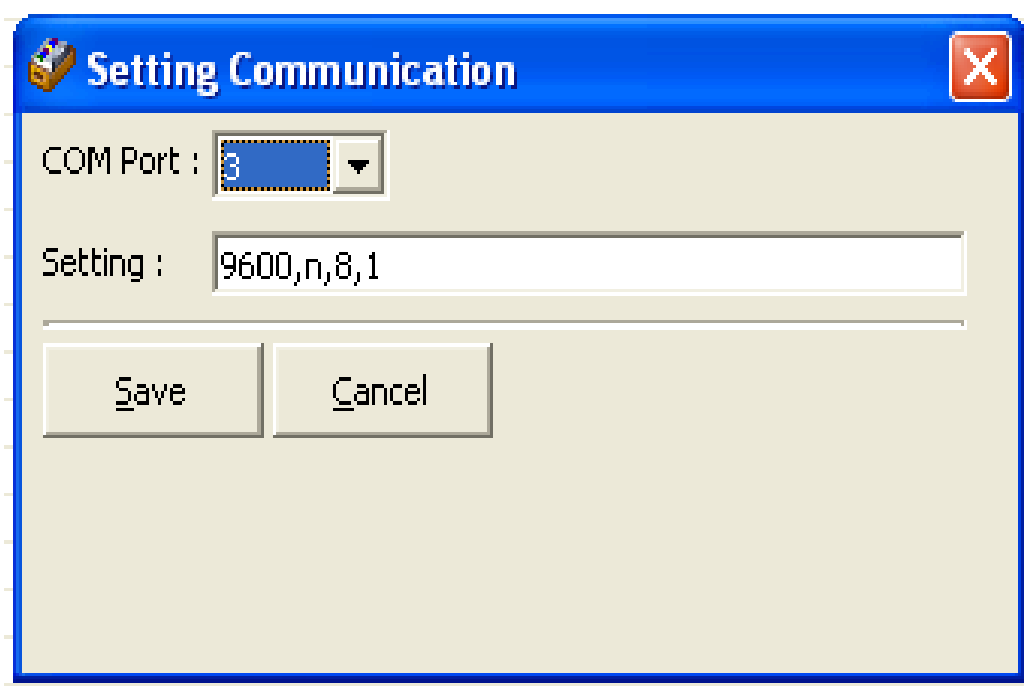

Figure 4: Port Settings on the System

The software used in the manufacture of this SMS system, among others:

1. Microsoft WindowsXP as the operating system.

2. MySQL 5.Oas databases.

3. Visual Basic 6.0 as a programming language.

4. AT Command GSM to access to Mobile.

\section{System Implementation}

In the implementation of this SMS system there are several programs that are used which these programs have different functions. The steps for implementing the SMS-based Exam Schedule Information System are as follows: Click "Master \& Tools" as shown below: 


\begin{tabular}{|c|c|c|}
\hline \multicolumn{3}{|c|}{ Master \& Tools } \\
\hline \multirow{4}{*}{$(8)$} & Data Dosen & Ctrl+D \\
\hline & Data Mata Kuliah & \\
\hline & Data ladwal Kuliah & Ctrl+] \\
\hline & SMS Âlerts & \\
\hline 8 & SMS Keluar & Ctrl+L \\
\hline 昆 & Setting Port & Ctrl+s \\
\hline (ii.) & Keluar & Ctrl+K \\
\hline
\end{tabular}

Figure 5: Master and Tools

\section{Lecturer Data Form}

Lecturer data is used to fill in lecturer data which consists of lecturer code and lecturer name. For more details, see the following image.

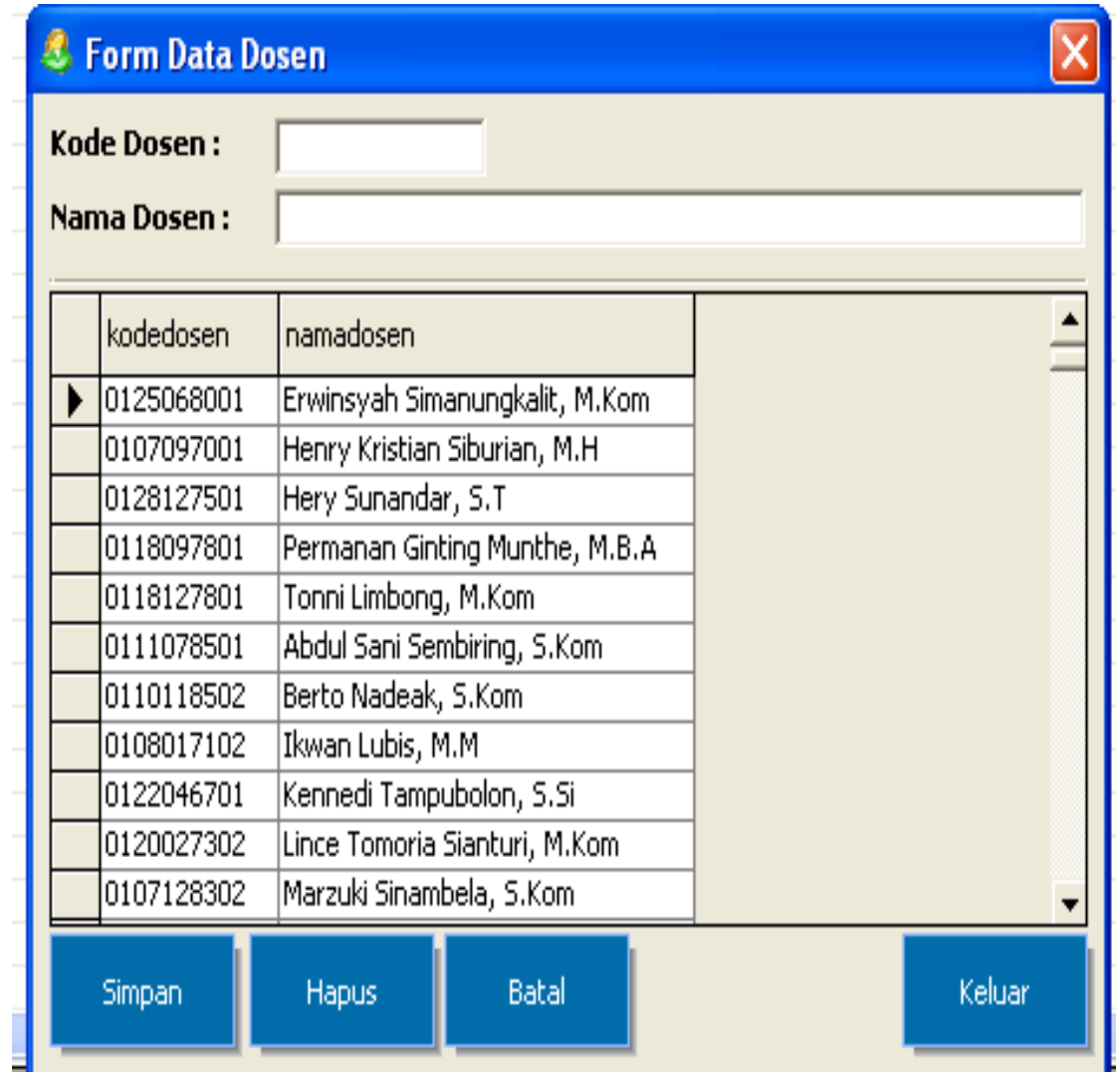

Figure 6: From Lecturer Data

\section{Course Data}

Course data is used to fill in course data consisting of course code, course name and credits. For more details, see the following image. 


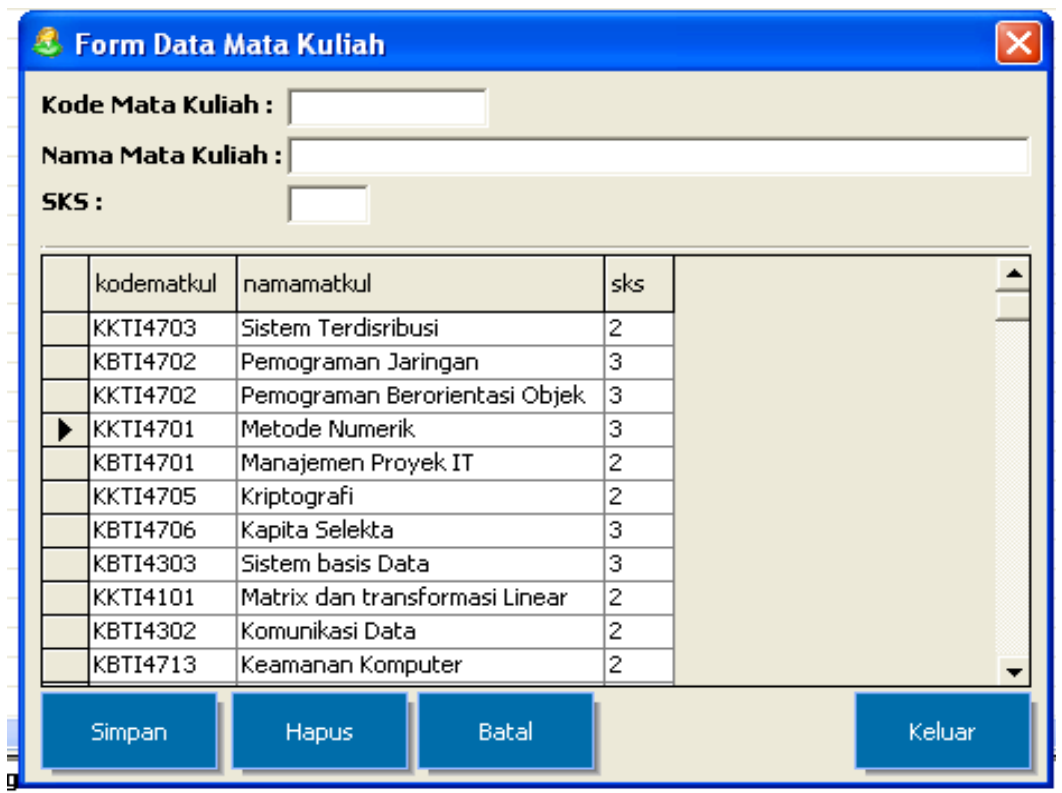

Figure 7 : From Course Data

\section{Course Schedule Data Form}

Course schedule data is used to fill in course schedule data consisting of majors, levels, classes, theories, semesters, courses, days, hours, rooms, lecturers. For more details, see the following image.

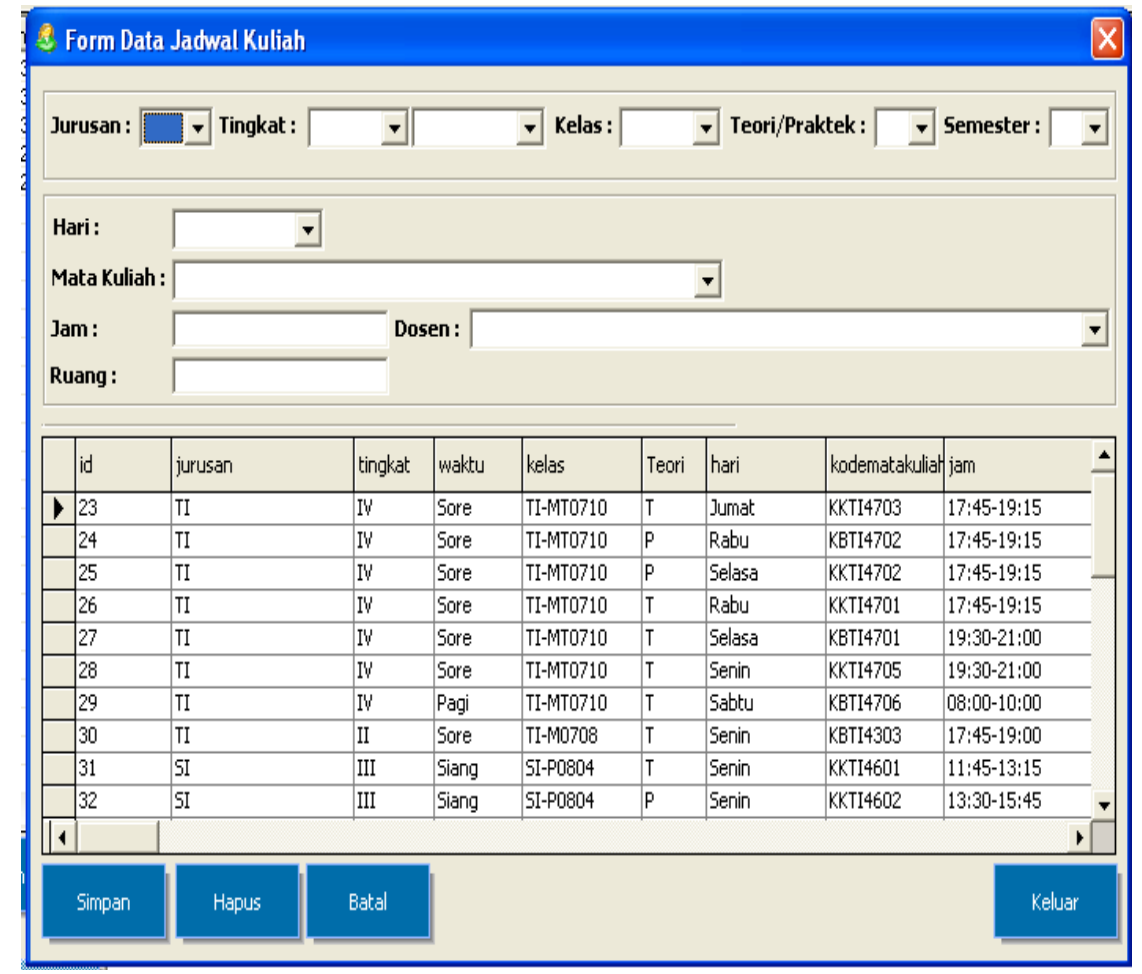

Figure 8 : From Course Schedule Data

\section{Incoming SMS Form}

The incoming SMS form is used to view the incoming SMS number with the message 
content or message format requested by the student.

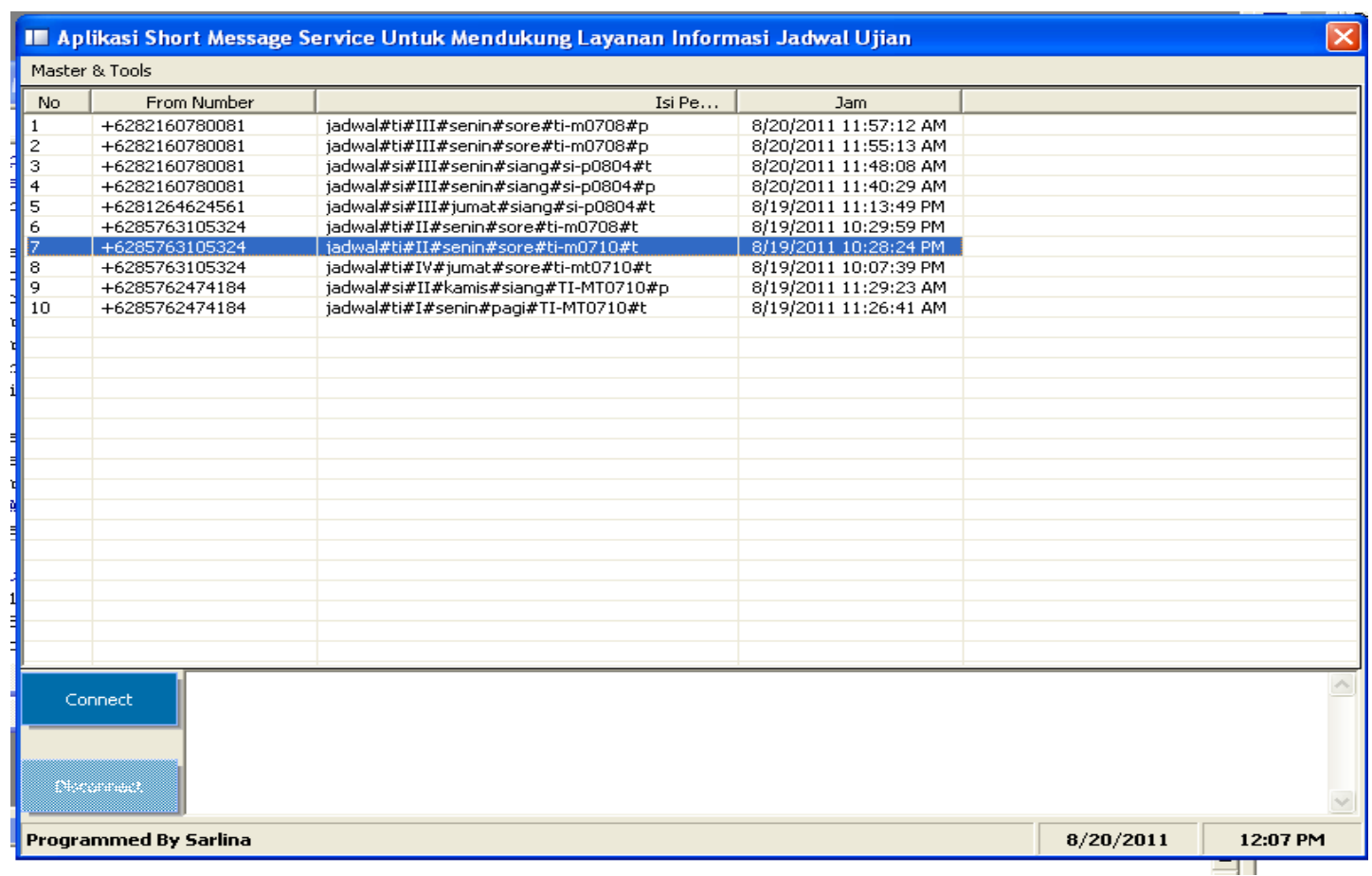

Figure 9 : From Incoming SMS

\section{SMS sending}

Sending this SMS is done by students by typing the SMS format that has been determined by the bureaucracy. The system will reply according to the SMS format automatically. If in accordance with the request, then the requested request will be sent in full. For more details on how to send SMS requested by students, see the following picture:

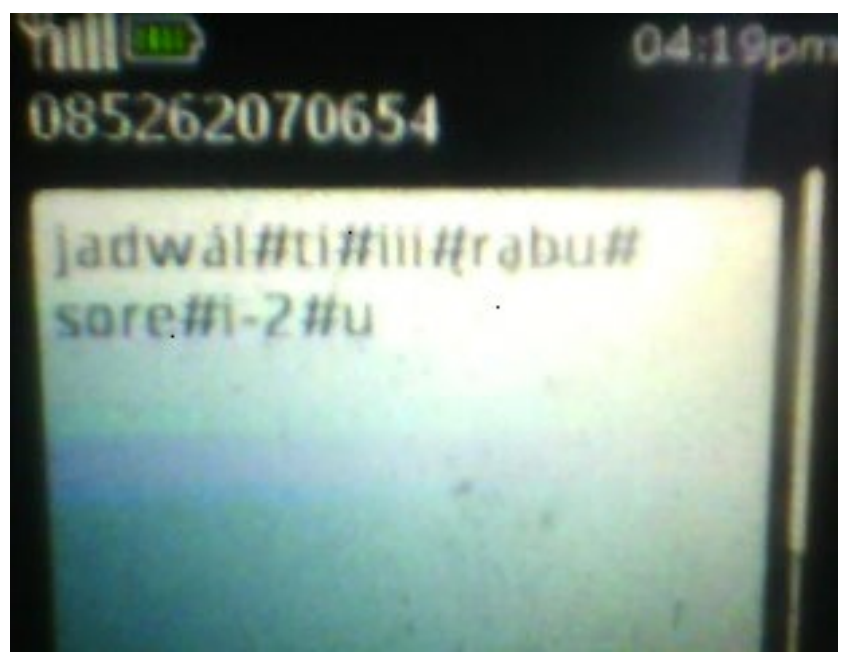

Figure 10 : SMS Sending Format

In the picture above, the student makes a theoretical schedule request to the server. The contents of the message requested by the student are already stored in the system. The process of sending SMS from the system which is an SMS reply from student requests 
according to the requested format. Which is shown in the following image.

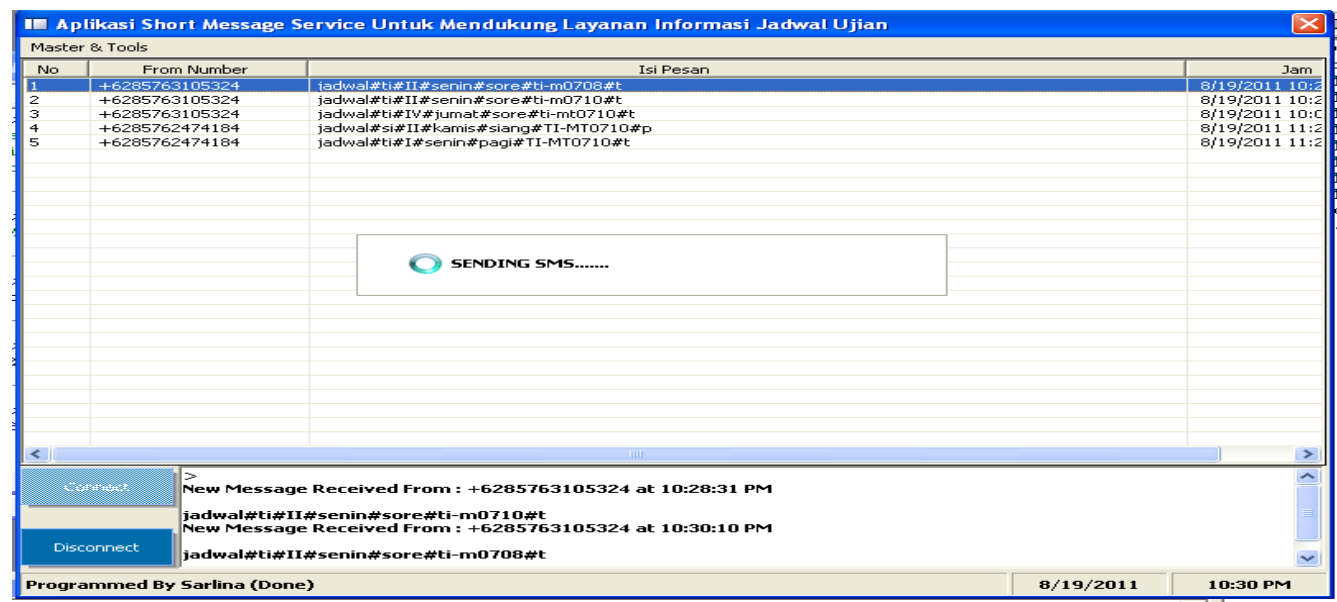

Figure 11 : SMS Sending Process

In the picture above, it can be seen that the process of sending messages automatically that has been successfully sent is shown in the following picture.

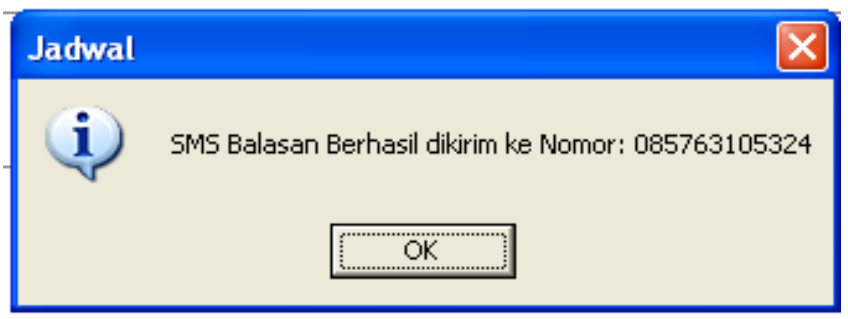

Figure 12 Successfully Sent SMS

\section{SMS Reply}

This SMS reply is sent from the system automatically. The contents of the SMS correspond to the format requested by the student, namely the theoretical schedule. For more details, see the following image:

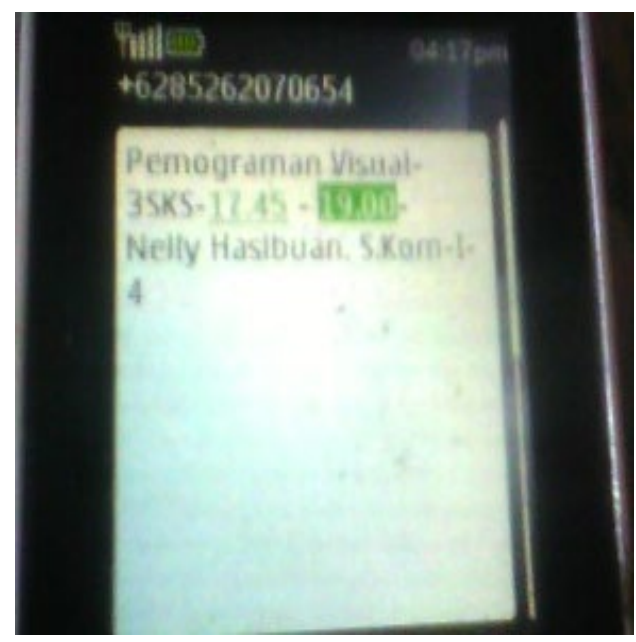

Figure 13 : SMS Reply 


\section{SMS Alert}

This SMS alert is used to notify students if there is a schedule change at any time. For more details, see the following image.

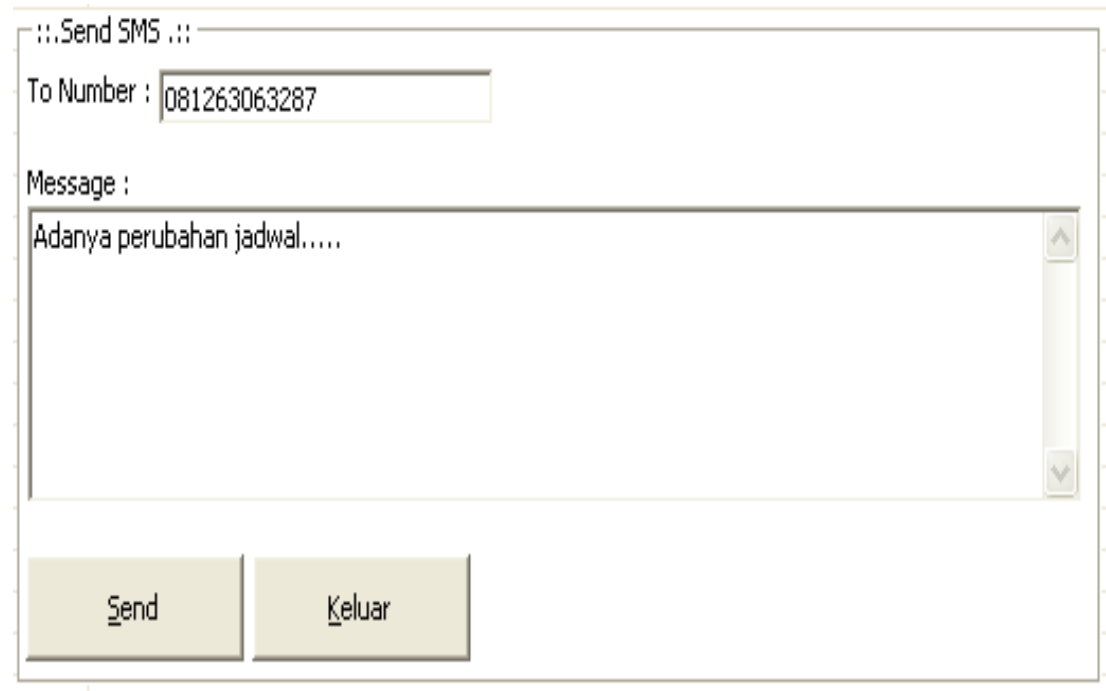

Figure 14 : SMS Alert

\section{Outbox}

Outbox form is used to view outgoing SMS reports consisting of destination number, SMS content, and delivery time.

\begin{tabular}{|c|c|c|c|}
\hline \multicolumn{3}{|c|}{ W FORM Kotak Keluar } & $x$ \\
\hline \multicolumn{4}{|c|}{ KOTAK KELUAR } \\
\hline To & IsisMS & TanggalJam & $\Delta$ \\
\hline 085763105324 & Tidak ada Jadwal untuk tersebut & 8/18/2011 2:21:43 PM & \\
\hline 085763105324 & Tidak ada Jadwal untuk tersebut & 8/18/2011 2:26:19 PM & \\
\hline 085763105324 & Tidak ada Jadwal untuk tersebut & 8/18/2011 2:33:36 PM & \\
\hline 085763105324 & Tidak ada Jadwal untuk tersebut & $8 / 19 / 201110: 51: 16 \mathrm{Al}^{*}$ & \\
\hline 081370544984 & Tidak ada Jadwal untuk tersebut & $8 / 19 / 201110: 55: 48 \mathrm{AN}^{*}$ & \\
\hline 085762474184 & Kapita Selekta-35K5-08.15-10.00 & $58 / 19 / 201111: 27: 11 \mathrm{Am}$ & \\
\hline 085762474184 & Metode Numerik-35KS-12,00-14. & $8 / 19 / 201111: 29: 49 \mathrm{Al}^{*}$ & \\
\hline 085763105324 & Sistem Terdisribusi-25KS-17:45-1 & $8 / 19 / 201110: 08: 03 \mathrm{PN}$ & \\
\hline 085763105324 & Tidak ada Jadwal untuk tersebut & $8 / 19 / 201110: 28: 37 \mathrm{PN}^{-1}$ & \\
\hline 085763105324 & Sistem basis Data-35K5-17:45-19 & e8/19/2011 10:30:54 PN & \\
\hline \multirow[b]{2}{*}{ Refresh } & & + & $\checkmark$ \\
\hline & Delete All & Keluar & \\
\hline
\end{tabular}

Figure 15 : Outbox Form

Sending messages for scheduling to make it easier for users to receive information with the sender's workflow sending a lecture schedule message will be filtered in the SMSC and then sent to the recipient. Messages sent by the sender are not immediately received by the recipient must go through the Service Message Service.

\section{CONCLUSION}


Based on the results of the research and discussion that has been done, the authors can conclude that this system can make it easier for students to get exam schedule information quickly and anywhere. The system designed is an SMS-based student exam schedule information system using AT Command GSM which is used as a command in communication with the serial port. This system only uses GSM network and is capable of receiving a maximum of 1 SMS request.

\section{REFERENCES}

[1] FP Sihotang and FS Jumeilah, "Interactive SMS-Based Tuition Payment Information Service at XYZ High School," JATISI (Journal of Tech. Inform. and Information System), vol. 4, no. 2, 2018, doi:10.35957/jatisi.v4i2.95.

[2] I. Ikbal, MR Effendi, and S. Mauluddin, "Reengineering of lecture scheduling information systems," SYSTEMIC, vol. 6, no. 3, 2018.

[3] F. Ramadhan, "Android Based Campus Academic Activity E-Reminder Application (Case Study: Information Systems Study Program UIN Suska)," J. UIN Sultan Syarif Kasim, Riau, 2018.

[4] M. Bagir, A. Supriyanto, and A. Arrosyidi, "Design of an Academic Information System at the Adi Husada Surabaya Academy of Nursing Web-Based," JSIKA, vol. 7, no. 3, 2018.

[5] I. KUSUMA W, "Design \& manufacture of an android-based student final project service information system application," Fac. Tech. Univ. Muhammadiyah Surakarta, 2017.

[6] VRH - AMIK BSI Purwokerto, RW - STMIK Nusa Mandiri Jakarta, and AA AMIK BSI Purwokerto, "WEB-BASED REGISTRATION INFORMATION SYSTEM ON THE BKK (SPECIAL WORK EXCHANGE) TUNAS INSAN KARYA SMK NEGERI 2 BANYUMAS," J. Evolution of Science and Management., vol. 6, no. 1, 2018, doi:10.31294/evolution.v6i1.3584.

[7] AS Rafika, DI Putri, and S. Sanusi, "THE PAYMENT SYSTEM OF TUITION FEES AT RAHARJA HIGH SCHOOL USING GO+," J. STORY, vol. 3, no. 1, 2017, doi:10.33050/story.v3i1.621.

[8] D. Susilawati, Rohman Hospital, S. Suhada, and D. Prayudi, "SMS Gateway-Based Loan Payment Reminder Information System for the PKK Sejahtera Cooperative," Sis. inf. Free Loan Payment Reminder. SMS Gatew. On Cop. Prosperous PKK., vol. 1, no. 1, 2018.

[9] WA Indra, FB Morad, N. Binti, M. Yusof, S. Asma, and C. Aziz, "GSM-Based Smart Energy Meter with Arduino Uno," int. J. Appl. eng. res., vol. 13, no. 6, 2018.

[10] BR Pampori, T. Mehraj, BUI Khan, AM Baba, and ZA Najar, "Securely eradicating cellular dependency for e-banking applications," int. J. Adv. Comput. science. app., vol. 9, no. 2, 2018, doi:10.14569/IJACSA.2018.090253.

[11] K. David and H. Berndt, "6G Vision and requirements: Is there any need for beyond 5g?," IEEE Veh. Technol. Mag., vol. 13, no. 3, 2018, doi:10.109/MVT.2018.2848498.

[12] K. Saravanan, E. Anusuya, R. Kumar, and LH Son, "Real-time water quality monitoring using Internet of Things in SCADA," environment. monit. Assess., vol. 190, no. 9, 2018, doi:10.1007/s10661-018-6914-x.

[13] S. Suradi, A. Hanafie, and S. Satriani, "DESIGN OF ROOM TEMPERATURE MONITORING SYSTEM BASED ON SHORT MESSAGE SERVICE USING ARDUINO NANO," ILTEK J. Teknol., vol. 13, no. 02, 2018, doi:10.47398/iltek.v13i02.372.

[14] S. Risnanto, "ELECTRONIC VOTING/E-VOTING APPLICATION USING 
SHORT MESSAGE SERVICE AND AT COMMAND TECHNOLOGY," J. Tek. Inform., vol. 10, no. 1, 2018, doi:10.15408/jti.v10i1.6811.

[15] M. Tubagus, "Short Massage Service (SMS) Development Model on Cellular Networks," Thinker Portrait., vol. 22, no. 2, 2018, doi:10.30984/pp.v22i2.783.

[16] AF Santamaria, M. Tropea, P. Fazio, and F. De Rango, "Managing emergency situations in VANET through heterogeneous technologies cooperation," Sensors (Switzerland), vol. 18, no. 5, 2018, doi:10.3390/s18051461.

[17] A. Delia Jurcut, M. Liyanage, J. Chen, C. Gyorodi, and J. He, "On the security verification of a short message service protocol," in IEEE Wireless Communications and Networking Conference, WCNC, 2018, vol. 2018-April, doi:10.109/WCNC.2018.8377349. 